\title{
Genotoxic potential generated by biomass burning in the Brazilian Legal Amazon by Tradescantia micronucleus bioassay: a toxicity assessment study
}

\author{
Herbert A Sisenando ${ }^{1,5^{*}}$, Silvia R Batistuzzo de Medeiros ${ }^{2}$, Paulo HN Saldiva ${ }^{3}$, Paulo Artaxo ${ }^{4}$ and Sandra S Hacon ${ }^{1}$
}

\begin{abstract}
Background: The Brazilian Amazon has suffered impacts from non-sustainable economic development, especially owing to the expansion of agricultural commodities into forest areas. The Tangará da Serra region, located in the southern of the Legal Amazon, is characterized by non-mechanized sugar cane production. In addition, it lies on the dispersion path of the pollution plume generated by biomass burning. The aim of this study was to assess the genotoxic potential of the atmosphere in the Tangará da Serra region, using Tradescantia pallida as in situ bioindicator.

Methods: The study was conducted during the dry and rainy seasons, where the plants were exposed to two types of exposure, active and passive.

Results: The results showed that in all the sampling seasons, irrespective of exposure type, there was an increase in micronucleus frequency, compared to control and that it was statistically significant in the dry season. A strong and significant relationship was also observed between the increase in micronucleus incidence and the rise in fine particulate matter, and hospital morbidity from respiratory diseases in children.

Conclusions: Based on the results, we demonstrated that pollutants generated by biomass burning in the Brazilian Amazon can induce genetic damage in test plants that was more prominent during dry season, and correlated with the level of particulates and elevated respiratory morbidity.
\end{abstract}

\section{Background}

The Amazon is located in the northern portion of South America and $85 \%$ of its area lies within Brazilian territory, where it is known as "Brazilian Amazon Region" and accounting for $61 \%$ of the country's area. The region has been negatively affected by advancing economic development, especially agribusiness and cattle raising. This has provoked changes in soil pattern use, resulting in increased deforestation and an increase in biomass burning in both native forest and pasture areas $[1,2]$. Sugar cane is an example of agribusiness that is in full expansion in the Amazon biome, driven by the

\footnotetext{
* Correspondence: herbertsisenando@yahoo.com.br

'Escola Nacional de Saúde Pública - ENSP, Fiocruz, Rio de Janeiro, CEP: 21041-210, RJ, Brazil

Full list of author information is available at the end of the article
}

political incentive to produce and consume biofuel both nationally and internationally. Brazil is one of the largest producers of biofuel worldwide, with most production concentrated in the Midwest region. Sugar cane straw burning at harvest time is widely used in Brazilian production to facilitate harvesting and increase the yield of manual cutting; however, this archaic procedure results in increased pollutant concentration in the atmosphere [3-6].

The Amazon accounts for $62 \%$ of the burnings that occur in Brazil during the dry and intermediate, dry and rain periods. The southern region of the Amazon had the largest number of biomass burning sites in the period from 2004 to 2007 [7]. Biomass burning is an organic matter combustion process, characterized by the release of different toxic compounds into the

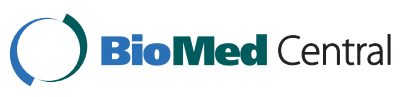


atmosphere. These include carbon monoxide, nitrogen oxides, sulfur oxides, particulate matter and polycyclic aromatic hydrocarbons (PAHs), as well as the formation of ozone as a secondary pollutant [8-12].

In terms of the harm to human health associated with exposure to biomass burning pollutants, it is known that children, the elderly and individuals with previous cardiorespiratory diseases, including asthmatics, are the most susceptible to the effects of exposure to air pollution. Respiratory diseases are part of a group of more easily identified consequences; however, pollution may trigger cardiovascular diseases and other disorders, especially in children [13-17]. Studies have demonstrated that an increase in air pollution levels is associated to a rise in the number of hospitalizations for respiratory diseases [18-21].

The presence of a determinate pollutant or of a complex mixture may have the capacity, at high concentrations or after long exposure, of inducing genotoxic effects not only in humans, but also in animals, plants and bacteria, possibly compromising the health of ecosystems [22]. Among the tests used to assess the mutagenic potential of air pollutants are micronucleus bioassays with plants. This type of assay was first used by Evans [23] in in vitro experiments with the Vicia faba root, and is now widely used in studies aimed at environmental monitoring through the use of other plant models such as Allium cepa and Tradescantia sp [24]. The micronucleus test in Tradescantia pallida (Trad-MCN) is considered a valuable tool by many researchers, due to the simplicity of the methodology and sensitivity of this plant to genotoxic agents [25]. Micronuclei are structures resulting from whole chromosomes or chromosomal fragments that are lost during cell division and, for this reason, are not included in the nucleus of daughter cells, remaining in the cytoplasm of interphase cells, allowing us to detect the action of clastogenic and aneugenic agents [26]. The relationship between exposure to air pollution and micronucleus synthesis was described by Souza-Lima et al. [27] in a study with ozone, by Alves et al. [28] in a study with PAH and by Carvalho-Oliveira et al. [29] in work involving $\mathrm{PM}_{2.5}$.

The aim of this study was to assess the genotoxicity potential of biomass burning pollutants using Tradescantia pallida in two exposure models, associating micronucleus frequency with pollutant concentrations in the region and with the rate of hospitalization for respiratory diseases in children in 2008-2009.

\section{Methods}

\section{Study region}

The study was conducted in the Tangará da Serra microregion in a population of 152,422 inhabitants distributed over an area of $23,728,712 \mathrm{~km}^{2}$, located in the southern of the Legal Amazon, encompassing the municipalities of Barra do Bugres (BB), Denise (DE), Nova Olímpia (NO) and Tangará da Serra (T-1 and T-2) (Figure 1). All cities received 1 monitoring station for the Tradescantia-micronucleus test except Tangará da Serra (T) that received 2 stations for being the main community in the microregion and shows the worst indicators of morbidity from respiratory diseases in the region $[30,31]$. The region is located in a transition area between the Amazon biome and the Cerrado, with typical cycles of drought and rain that alter air pollution levels, and lies in the dispersion path of the pollution plume resulting from burnings in the Legal Amazon and pollution emanating from neighboring countries $[5,32,33]$. The region is the largest sugar cane producer and contains the two largest plants in the southern of the Brazilian Amazon [34]. The municipality of Chapada dos Guimarães, Brazil $(\mathrm{CH})$ was selected as control area in this study because of its better air quality. There is no industrial production or sugar cane burning and automobile traffic is light, compared to the other

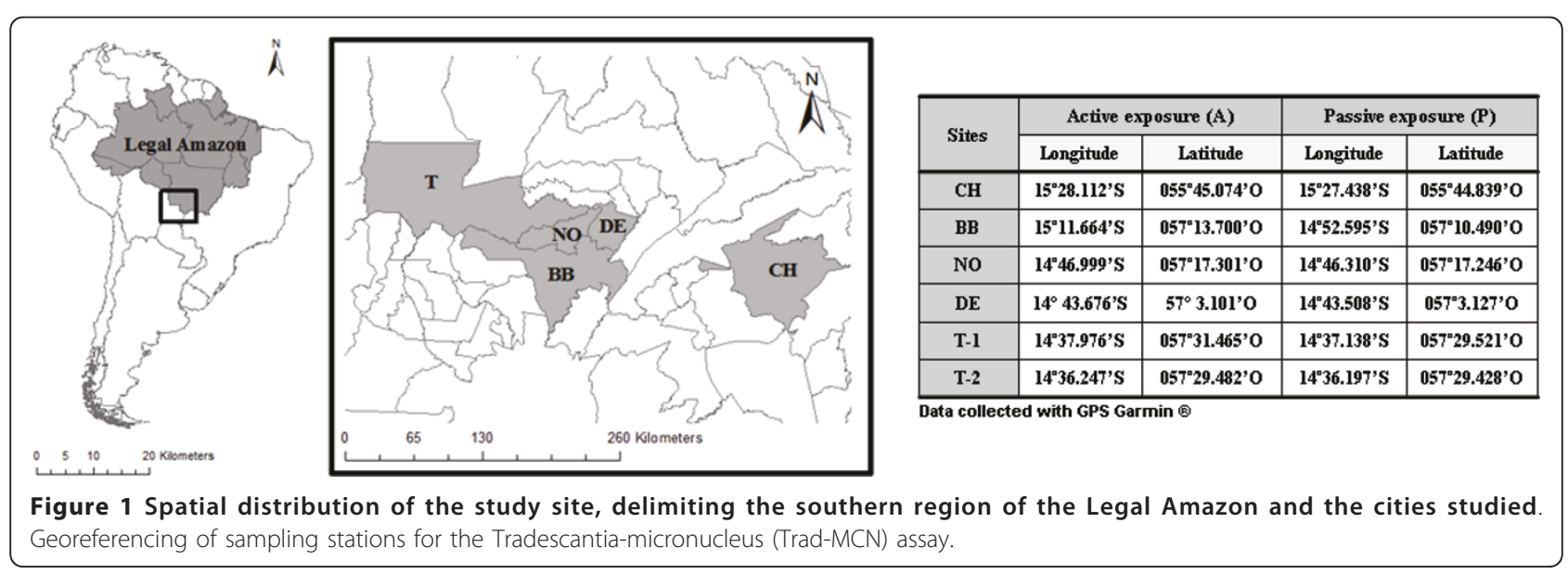


Table 1 Distribution of environmental and meteorological variables at all sampling stations.

\begin{tabular}{|c|c|c|c|c|c|c|}
\hline Variables & & $\mathrm{CH}$ & BB & NO & $\mathrm{DE}$ & $\mathrm{T}$ \\
\hline \multirow[t]{3}{*}{$\mathrm{PM}_{2.5}\left(\mu \mathrm{g} / \mathrm{m}^{3}\right)$} & $\mathrm{D}$ & $9.9(1.0)$ & $20.9(2.1)$ & $20.8(2.1)$ & $19.3(2.0)$ & $20.9(2.1)$ \\
\hline & R & $5.0(1.0)$ & $8.9(1.8)$ & $8.4(1.7)$ & $7.2(1.4)$ & $7.4(1.5)$ \\
\hline & Ratio D/R & 2.0 & 2.4 & 2.4 & 2.7 & 2.8 \\
\hline \multirow[t]{3}{*}{ Rainfall (mm/d) } & D & $1.1(1.0)$ & $1.0(0.8)$ & $1.1(0.9)$ & $0.9(0.8)$ & $0.9(0.8)$ \\
\hline & R & $9.8(1.0)$ & $11.1(1.1)$ & $11.7(1.2)$ & $11.6(1.2)$ & $12(1.2)$ \\
\hline & Ratio R/D & 8.9 & 11.1 & 10.6 & 12.9 & 13.3 \\
\hline \multirow[t]{3}{*}{ Temperature $\left({ }^{\circ} \mathrm{C}\right)$} & $\mathrm{D}$ & $25.9(1.0)$ & $25.4(1.0)$ & $25.1(1.0)$ & $25.4(1.0)$ & $24.6(0.9)$ \\
\hline & R & $25.4(1.0)$ & $25.2(1.0)$ & $24.8(1.0)$ & $25.0(1.0)$ & $24.4(1.0)$ \\
\hline & Ratio D/R & 1.0 & 1.0 & 1.0 & 1.0 & 1.0 \\
\hline \multirow[t]{3}{*}{ Humidity (\%) } & $\mathrm{D}$ & $51.2(1.0)$ & $55.7(1.1)$ & $56.3(1.1)$ & $55.3(1.1)$ & $57.4(1.1)$ \\
\hline & R & $80.5(1.0)$ & $82.5(1.0)$ & $83.4(1.0)$ & $83.0(1.0)$ & $84.2(1.0)$ \\
\hline & Ratio R/D & 1.6 & 1.5 & 1.5 & 1.5 & 1.5 \\
\hline
\end{tabular}

$\mathrm{D}=$ data obtained in the dry season. $\mathrm{R}=$ data obtained in the rainy season. $\mathrm{D} / \mathrm{R}=$ ratio between the dry and rainy season. $\mathrm{R} / \mathrm{D}=$ ratio between the rainy and dry season. The data in parentheses represent the ratio between the data of each test site and the control site $(\mathrm{CH})$.

municipalities involved. It was also chosen for the similarities in meteorological variables (rainfall, temperature and humidity) compared to other communities involved in this study (Table 1).

\section{Tradescantia pallida micronucleus assay}

In this study 2 types of assessment were used: Active and Passive. In active assessment, T. pallida were cultivated in vases $(50 \mathrm{~cm} \times 17 \mathrm{~cm} \times 17 \mathrm{~cm})$ containing organic soil, watered daily, as described by Meireles et al. [35] and Sisenando et al. [36]. After a plant adaptation period (3 months), the vases were placed in 6 sampling sites (Figure 1). Passive assessment was carried out at 6 points, using plants of the same species and that grew in public gardens in the cities evaluated in this work (Figure 1). The inclusion criteria for the passive assay points were the proximity to the points selected for active monitoring and the existence of cultivated plants for more than 1 year. Inflorescence collection was performed at the same time in the two assessment types, and during two different periods: the dry season (May/08 to October/08) and the rainy season (November/08 to April/09), in order to encompass the two climatic periods of the region. The inflorescences were fixed in ethanol-acetic acid solution (3:1) for 24 hours and transferred to a solution of $70 \%$ ethanol for storage [37]. The flower buds containing tetrads in their initial stages were dissected, mounted on slides and stained in $2 \%$ acetic-carmine, according to the protocol established by Ma et al. [37]. Analysis consisted of counting 300 cells in the tetrad stage per slide, totaling 3000 cells per sampling site, where mean micronucleus frequency $(\% \mathrm{MCN})$ was determined according to criteria adopted by Fenech [38].

\section{Environmental and health data collection}

Data on hospitalizations for respiratory diseases (Chapter $\mathrm{X} / \mathrm{ICD}-10)$ in the study region and in the control area, during the dry and rainy season, were obtained from databanks for the period of May/08 to April/09, available by the Ministry of Health of Brazil in relation to Hospitalization Authorizations (HA) of the Department of Informatics (website: http://www.datasus.gov. br). The standardized rate was calculated (number of hospitalizations/1000 inhabitants) for children (age $<5$ years), using population data from the Brazilian Institute of Geography and Statistics [31]. The children age group selected for this study is likely to be susceptible to the harmful effects of exposure to air pollution and less influenced by possible confounding factors (Ex.: alcohol and/or cigarette consumption) [39,40].

The daily means of air pollutant (fine particulate matter $-\mathrm{PM}_{2.5}$ ) and of meteorological variables (rainfall, humidity and temperature) in the region under the direct influence of burnings and in the control area, during the rainy and dry seasons, were obtained from CATT-BRAMS (Coupled Aerosol and Tracer Transport model of the Brazilian Regional Atmospheric Modeling System) accessed through SISAM (System of Environmental Information Integrated to Environmental Health - 2009). CATT-BRAMS is a 3D Eulerian model that allows a simultaneous prognosis of the concentration of determinate air pollutants, consistent with the atmospheric state simulated by the BRAMS model (based on the RAMS model). A more detailed description of this model was presented by Freitas et al. [11,41,42].

\section{Statistical analysis}

To assess statistically significant differences among the different test points compared to the control point, during each period, the Kruskal-Wallis test was used followed by the Dunn multiple comparisons test. The statistically significant differences between the responses obtained in the dry and rainy seasons were analyzed using the Mann-Whitney test. This same test was also 
used to assess the significance between the responses obtained in active and passive exposure at each sampling point and in both seasons.

Spearman's correlation was used to analyze the \% MCN obtained in active and passive exposure, as well as environmental and health data in the study region. The data were tabulated and analyzed using Microsoft Office ${ }^{\circledR} 2007$ and SPSS ${ }^{\circledR} 16.0$.

\section{Results}

Figure 1 shows the southern region of the Legal Amazon and the municipalities involved in this study, in addition to the georeferencing of all the points sampled in the Tradescantia-micronucleus (Trad-MCN) assay under both exposure situations.

Table 1 shows the mean concentration of the environmental $\left(\mathrm{PM}_{2.5}\right)$ and meteorological (rainfall, temperature and humidity) variables modeled by CATT-BRAMS in all the municipalities studied. In relation to meteorological variables, we observed that the rainy season showed accumulated rainfall 10 times higher than that observed in the dry season. We observed no differences (ratio = 1) in air temperature between the dry and rainy seasons, but relative air humidity in the rainy period was on average 1.5 times higher. When we compared the temperature and humidity data of each season with those of the control, we observed that the ratios varied between 0.9 and 1.1, suggesting no difference between the data. With respect to environmental variable, we found that $\mathrm{PM}_{2.5}$ demonstrated a profile in which the concentrations modeled in the dry season were about twice as high as the rainy season. When we compare the ratios obtained by dividing the data of each air pollutant exposure point by those obtained in the control, it can be observed that the exposure points were almost twice as large in the dry season and 1.5 times in the rainy season.

Mean micronucleus frequency $(\% \mathrm{MCN})$ in the active and passive exposures during the different periods is shown in Figures 2 and 3 respectively. The results of the two figures show that the \%MCN obtained in the dry

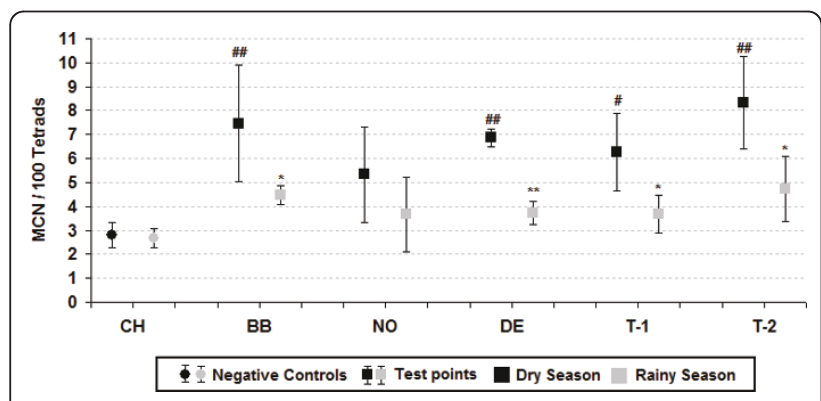

Figure 2 Active exposure, micronuclei frequency in $T$. pallida at the study sites. ${ }^{\#} p<0.05$ and ${ }^{\#} p<0.01$ by Kruskal-Wallis. ${ }^{*} p<$ 0.05 and ${ }^{* *} p<0.01$ by Mann-Whitney.

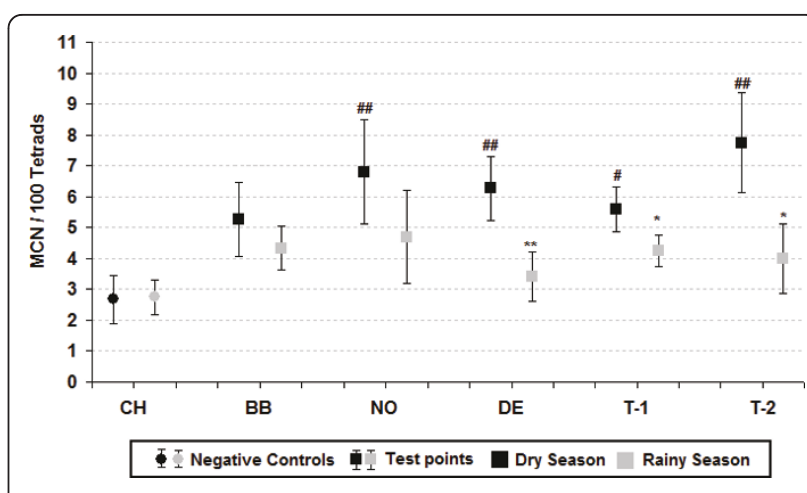

Figure 3 Passive exposure, micronuclei frequency in T. pallida at the study sites. ${ }^{\#} p<0.05$ and ${ }^{\# \#} p<0.01$ by Kruskal-Wallis. ${ }^{*} p<$ 0.05 and ${ }^{* *} p<0.01$ by Mann-Whitney.

season were higher than those obtained in the rainy period. Statistically significant differences occurred in 58\% of the sampling stations, especially the Denise and Tangará stations. A comparison between the micronucleus frequency of the test stations and the control station shows statistically significant differences in nearly all the comparisons during the dry season, unlike the rainy season, which exhibited no significant difference.

Figure 4 shows the distribution of $\% \mathrm{MCN}$ in the municipalities and a comparison of the responses of the different types of exposure and periods sampled. No statistically significant difference was found between the two types of exposure, although we observed a greater response in terms of the increased number of micronuclei, in active exposure compared to passive, regardless of the period. When the two types of exposure are correlated using Spearman's method, a statistically significant positive correlation was observed $(r=0.794 p=$ 0.006).

Table 2 shows Spearman's correlation coefficient between the \%MCN of each study area and their respective environmental and health data. Statistically significant positive correlations were detected between the \%

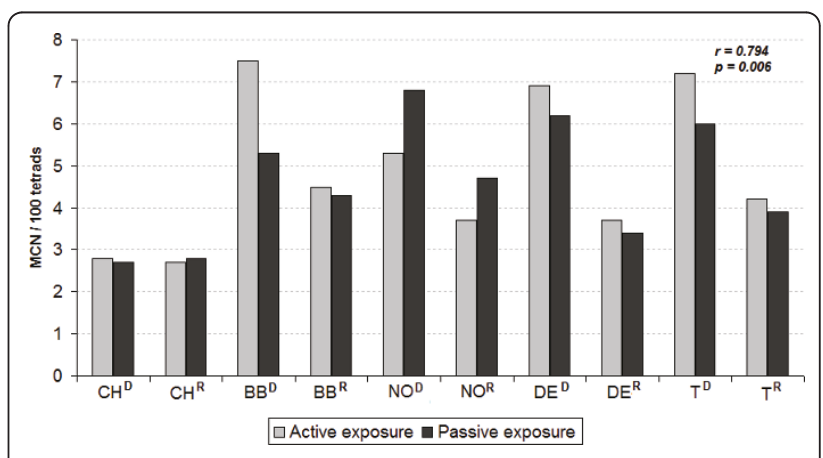

Figure 4 Micronucleus frequencies in T. pallida in active and passive monitoring. $\mathrm{D}=$ dry season. $\mathrm{R}=$ rainy season. Spearman's correlation coefficient ( $r$ and $p$ ) for the two types of exposure. 
Table 2 Correlation coefficients (and corresponding significance level) between the average micronucleus frequency of the sampling stations and the corresponding environmental and health data.

\begin{tabular}{|c|c|c|c|c|c|c|}
\hline Spearman's Correlation & $\mathrm{MCN}^{\mathrm{a}}$ & $\mathrm{PM}_{2.5}\left(\mu \mathrm{g} / \mathrm{m}^{3}\right)$ & Rainfall (mm/d) & Temperature $\left({ }^{\circ} \mathrm{C}\right)$ & Humidity (\%) & $\mathrm{RD}^{-\mathrm{C}^{\mathrm{b}}}$ \\
\hline \multirow[t]{2}{*}{$\mathrm{MCN}^{\mathrm{a}}$} & 1.000 & $.818^{* *}$ & $-.636^{*}$ & -.030 & -.297 & $.721^{*}$ \\
\hline & . & .004 & .048 & .934 & .405 & .019 \\
\hline \multirow[t]{2}{*}{$\mathrm{PM}_{2.5}\left(\mu \mathrm{g} / \mathrm{m}^{3}\right)$} & & 1.000 & $-.806^{* *}$ & .176 & -.612 & .467 \\
\hline & & & .005 & .627 & .060 & .174 \\
\hline \multirow[t]{2}{*}{ Rainfall $(\mathrm{mm} / \mathrm{d})$} & & & 1.000 & -.418 & $.806^{* *}$ & -.152 \\
\hline & & & & .229 & .005 & .676 \\
\hline \multirow[t]{2}{*}{ Temperature $\left({ }^{\circ} \mathrm{C}\right)$} & & & & 1.000 & $-.806^{* *}$ & -.467 \\
\hline & & & & . & .005 & .174 \\
\hline \multirow[t]{2}{*}{ Humidity (\%) } & & & & & 1.000 & .236 \\
\hline & & & & & & .511 \\
\hline
\end{tabular}

$\mathrm{a}=$ average micronuclei frequency under active exposure. $\mathrm{b}=$ adjusted rate of hospital morbidity from respiratory diseases in children (Chapter $\mathrm{X} / \mathrm{ICD}-10)$. Correlation is significant at the 0.05 level (2-tailed). ${ }^{* *}$ Correlation is significant at the 0.01 level (2-tailed). Data obtained in the dry and rainy period.

$\mathrm{MCN}$ and the means of the fine particulate matter $\mathrm{PM}_{2.5}(r=0.818 p=0.004)$ and the adjusted rate of hospital morbidity from respiratory diseases in children RD-C $(r=0.721 p=0.019)$. A substantial negative relationship was observed between micronucleus frequency and mean accumulated rainfall $(r=-0.636 p=0.048)$. No significant associations were found between micronucleus frequency and the other meteorological variables (temperature and humidity). An extremely significant correlation was observed between the means of fine particulate matter in relation to accumulated rainfall $(r=-0.806 p=0.005)$.

\section{Discussion}

The risk attributed to exposure to low levels of air pollution for human pathogenesis using only epidemiological tools requires long-term studies and the participation of a large number of individuals exposed to pollutants. This type of study has disadvantages such as the high operational cost and logistical complexity and because if the association is established, a considerable number of participants will already have developed the disease. Although plant mutagenesis and aggravated human health cannot be compared, the genotoxicity assay with $T$. pallida can be used as a screening tool to assess human risk under unfavorable environmental conditions [43].

With respect to environmental variables, studies by Alves et al. [28], Isidori et al. [22], Klumpp et al. [44] and Savóia et al. [45] show that air temperature may act as a possible confounding factor, promoting the increase in micronucleus frequency. In our study, this confounding factor was minimized by virtue of the climatological homogeneity of the points. This can be observed by the fact that the ratio between the temperature of each test station and that obtained in the control station ranged between 0.9 and 1.0. The micronucleus frequency found in the actively and passively exposed plants in the control area of Chapada dos Guimarães was similar to that observed in the control group of studies that also assessed the genotoxicity potential of compounds present in air pollution, conducted by Batalha et al. [46] and Guimarães et al. [25] in Brazil, Carreras et al. [43] in Argentina, and Prajapati \& Tripathi [47] in India.

The comparative results between the environmental and meteorological variables (Tab. 1) at the different points and exposure periods corroborate those reported by Rosa et al. [33] about the delimitation of two welldefined climatic periods (dry and rainy). This fact interferes significantly in the number of biomass burning points and pollutant dispersion, given that the pollution generated by biomass burning in the Amazon reaches its peak during the dry season [7]. Studies conducted by Andrade Júnior et al. [48], Savóia et al. [45] and Souza Lima et al. [27] to assess the genotoxicity of pollutants present in the atmosphere, using the Trad-MCN test also adopted a similar exposure sampling period. Although the literature contains studies that were conducted with much shorter exposure periods, the results remained significant $[43,47,49]$. In relation to micronucleus frequency, the results show that the response obtained in the dry season was higher than those in the rainy season at $92 \%$ of the points and statistically significant at most of them, irrespective of exposure type. These findings may be explained by the fact that in the dry season there are a larger number of hotspots generated by biomass and sugar cane straw burning and thus higher levels of air pollutants, especially fine particulate matter. Regardless of the type of exposure, when we compare the results obtained at the test points compared to control, we 
observe that, unlike the dry season, there are no significant differences in the rainy period. This may be owing to the lower number of burnings in this period [7], which generates a lower concentration of pollutants emitted into the troposphere and, associated to greater pollutant dispersion [50] during the rainy period, produced a reduction in \% $\mathrm{MCN}$ at all the test points, in both exposures (active and passive).

When we analyze only \% MCN of the dry season, we observe that stations DE, T-1 and T-2 showed the most important results, given that they were all statistically significant in both types of exposure. The response exhibited at station DE may be directly related to the proximity of the largest sugar cane plant of the region and to the fact that the municipality is the second largest sugar cane producer in the area, which contains large plantations surrounding the city limits where nonmechanized harvesting is still practiced [34]. The results of stations $\mathrm{T}$ (T-1 and T-2), both for micronuclei and pollutant levels, corroborate Ignotti et al. [30] and Rosa et al. [33], whose studies show that Tangará da Serra exhibits one of the worst indicators of morbidity and mortality from respiratory diseases in the southern region of Brazilian Amazon.

A comparison of \% MCN obtained in the two types of exposure shows a very strong and statistically significant correlation $(r=0.794 p=0.006)$, although there is an underestimation of passive compared to active response, in relation to the genotoxicity potential generated by air pollution. Other studies that used these two types of exposure simultaneously also obtained similar results when they evaluated the genotoxicity potential generated by pollutants emitted by the burning of fossil fuels in the cities of Feira de Santana/Brazil [35] and São Paulo/ Brazil [25] using T. pallida. Meireles et al. [35] suggested that the difference between the two types of exposure may be due to an adaptation process of the plant, under passive exposure, to air pollutants at the exposure site. This likely adaptation of Tradescantia to air pollution was explained by Alves et al. [51], in a study conducted in São Paulo, Brazil, in which the reduction in stomata size on the abaxial surface of the leaves (region sensitive to air pollutants) after exposure to air pollutants, which provokes a reduction in gas exchange capacity and consequently in the possible effects that pollution has on the plant.

In terms of public health, the particulate matter is an important pollutant emitted into the atmosphere. Although the concentrations of fine particulate matter obtained in this study have been below the level suggested by the World Health Organization who is $25 \mu \mathrm{g} /$ $\mathrm{m}^{3} / 24 \mathrm{~h}$, it is important to report that WHO in its Air Quality Guidelines show that the continuous exposure $\mathrm{PM}_{2.5}$ concentrations even below the level suggested may increase the risks to the population exposed [52]. Studies conducted by Annesi-Maesano et al. [53] in France, Braga et al. [54] and Cançado et al. [20] in Brazil, Casas et al. [55] in Chile and Rojas-Martinez et al. [56] in México report a significant positive relationship between exposure to air pollutants and the increasing incidence of aggravated health in children. The main risk factor from this exposure is the capacity that these pollutants have to compromise pulmonary development [57], which causes impaired lung growth in children, increasing the risk of developing chronic obstructive pulmonary disease at adult age, as well as increased morbidity and mortality from cardiovascular diseases [56].

When we correlated the values of $\mathrm{PM}_{2.5}$ during the entire period with the \% $\mathrm{MCN}$ of active exposure, we observed a positive and extremely significant correlation $(r$ $=0.818 p=0.004)$, corroborating the results obtained by Batalha et al. [46], Carvalho-Oliveira et al. [29], Carreras et al. [43] and Prajapati \& Tripathi [47]. All these results show the importance of this biomarker in the evaluating genotoxic damage caused by exposure to particulate matter generated by burning biomass. The fact that we observed no significant correlation between \%MCN and air temperature $(r=-0.30 p=0.934)$, contrasts with work published by Isidori et al. [22], Klumpp et al.[44] and Savóia et al. [45]. This may be owing to the similarity in temperature data from all the points, regardless of the period, a situation that reduces the confounding factor. When we correlated rainfall with $\mathrm{PM}_{2.5}$ data $(r=-0.806 p=$ 0.005 ), we found a significant negative relationship, which shows that rain has a strong influence of biomass burning in the region. Indirectly, we observed that rainfall also has an important influence on micronucleus indices $(r=$ $-0.636 p=0.048$ ), since it reduces the number of burning points and pollutants emitted into the air.

The fact that we observed no statistically significant correlation between RD-C and the fine particulate matter $(r=0.467 p=0.174)$ does not rule out the capacity of the latter to compromise the health of sensitive individuals. Mazzoli-Rocha et al. [58], in a study conducted with BALB/c mice exposed to particulate matter from sugar cane burning in Araraquara, Brazil, observed that the particulate matter collected in filters may induce alterations in the mechanics and pulmonary histology of the exposed mice, causing an increase in polymorphonuclear (PMN) cells and a reduction in mononuclear $(\mathrm{MN})$ cells in the pulmonary parenchyma compared to the control.

A study carried out by Mariani et al. [49] in São José dos Campos, Brazil showed that micronucleus frequency in T. pallida exposed to air pollution was significantly associated to the mortality rate (deaths/10,000 inhabitants) adjusted for cardiovascular diseases $(r=0.841 p=$ $0.036)$ and cancer $(r=0.890 p=0.018)$ in the general 
population. The authors showed that there was a substantial relationship, albeit not significant, between micronucleus indices and mortality from chronic obstructive pulmonary disease $(r=0.640 p=0.170)$. These data corroborate the result obtained for the relationship between the standardized rate (hospital morbidity/1000 inhabitants) in children (RD-C) and \%MCN $(r$ $=0.721 p=0.019$ ), showing a strong, statistically significant positive correlation between the two variables.

A factor that could be considered a limitation of this study was the number of vases with $T$. pallida at each point of the active exposure, which limited the number of inflorescences analyzed by point and that may have contributed to the large standard deviation in some stations. Another limitation was the analysis of all Chapter $\mathrm{X} / \mathrm{ICD}-10$ for construction of the adjusted morbidity rate in children since not all diseases in this chapter are related to exposure to air pollutants. However, this measure was necessary to minimize failures in the procedures for notification of diseases by the health system observed by Rosa et al. [33] in a study that analyzed the magnitude of the hospital admissions for respiratory diseases in the region. This study observed that the increase in notifications due to pneumonia can be explained by the higher financial remuneration of this type of procedure as compared with hospitalizations for asthma. Another important factor noted by Rosa et al. [33] and that influencing the clinical diagnosis of asthma in the region was the prejudice of the parents in accepting that the child has the disease.

\section{Conclusions}

The present work is a pioneer study on the assessment of genotoxic potential caused by biomass burning in the Legal Amazon region, Furthermore, it showed that in situ biomonitoring using a sensitive organism (Tradescantia pallida Purpurea) may be an important tool for monitoring air quality in regions that do not contain environmental monitoring stations. Considering that pollution generated by biomass burning is a complex mixture, it is difficult to attribute the increase in \%MCN observed in our study to any toxic element integrated in the particular matters. However, the contribution of the present study lies the fact that we found significant relationship between the increase in micronucleus frequency and the increased exposure to fine particulate matter. It was also observed that this rise in micronucleus frequency was significantly correlated with the increase in the standardized rate of respiratory diseases in children, suggesting that research using Tradescantia pallida is an important biological indicator to be included in the assessment of human risk to exposure to toxic agents emitted by biomass burning.

\section{List of Abbreviations}

DNA: Deoxyribonucleic Acid; PAHs: Polycyclic Aromatic Hydrocarbons; TradMCN: Micronucleus Test in Tradescantia pallida; PM $_{2.5}$ : Fine Particulate Matter BB: Barra do Bugres, DE: Denise; NO: Nova Olímpia; T: Tangará da Serra; T1: Tangará da Serra - station 1; T2: Tangará da Serra - station 2; CH: Chapada dos Guimarães; \%MCN: Mean Micronucleus Frequency; ICD-10: International Statistical Classification of Diseases - 10th Revision; HA: Hospitalization Authorizations; CATT-BRAMS: Coupled Aerosol and Tracer Transport Model of the Brazilian Regional Atmospheric Modeling System; SISAM: System of Environmental Information Integrated to Environmental Health; RD-C: Adjusted Rate of Hospital Morbidity from Respiratory Diseases in Children; PM: Particulate Matter; PMN: Polymorphonuclear; MN: Mononuclear Cells.

\section{Acknowledgements}

This study was made possible by a Grant provided by CNPq/INCT/MCT N ${ }^{\circ}$ : 573797/2008-CNPq/CT-18, and the logistical support of the Universidade do Estado do Mato Grosso (UNEMAT), the Laboratório de Mutagênese Ambiental (LAMA/UFRN) and the Centro de Estudos da Saúde do Trabalhador e Ecologia Humana (CESTEH/ENSP/FIOCRUZ). The authors are grateful to Eliane Ignotti, Rivanildo Dallacort, Maurecilne Lemes da Silva Carvalho and Evânia Leite de Oliveira for support in developing this project.

\section{Author details}

'Escola Nacional de Saúde Pública - ENSP, Fiocruz, Rio de Janeiro, CEP: 21041-210, RJ, Brazil. 'Departamento de Biologia Celular e Genética, UFRN, Natal, CEP: 59072-970, RN, Brazil. ${ }^{3}$ Departamento de Patologia, USP, São Paulo, CEP: 01246-903, SP, Brazil. ${ }^{4}$ Departamento de Física Aplicada, USP, São Paulo, CEP: 05508-900, SP, Brazil. ${ }^{5}$ Departamento de Patologia, UFF, Niterói, CEP: 24033-900, RJ, Brazil.

\section{Authors' contributions}

HAS participated in the study design, conducted the analyses, and drafted the manuscript; SRBM participated in the study design, guided the genotoxicity analyses, and reviewed the manuscript drafts; PHNS guided the Tradescantia pallida assay, and reviewed the manuscript drafts; PA was involved in revision and preparation of the manuscript for publication; SSH conceived of the study, participated in its design and coordination and helped to draft the manuscript. All authors read and approved the final manuscript.

\section{Competing interests}

The authors declare that they have no competing interests.

Received: 13 January 2011 Accepted: 17 May 2011

Published: 17 May 2011

\section{References}

1. Artaxo P, Martins JV, Yamasoe MA, Procópio AS, Pauliquevis TM, Andreae MO, Guyon P, Gatti LV, Leal AMC: Physical and chemical properties of aerosols in the wet and dry seasons in Rondônia, Amazonia. J Geophys Res 2002, 107:8.081-088.095.

2. Ferreira DAC, Nogueira SP, Carneiro-Filho A, Soares-Filho B: Mato, grosso até quando? Cienc Hoje 2008, 42:26-31.

3. Magalhães D, Bruns RE, Vasconcellos PC: Polycyclic aromatic hydrocarbons as sugarcane burning tracers: a statistical approach. Quim Nova 2007, 30:577-581.

4. Moraes MAFD: O mercado de trabalho da agroindústria canavieira: desafios e oportunidades. Econ Apl 2007, 11:605-619.

5. Rosa AM, Ignotti E, Botelho C, Castro HA, Hacon SS: Respiratory disease and climatic seasonality in children under 15 years old in a town in the Brazilian Amazon. J Pediatr 2008, 84:543-549.

6. Yield of sugarcane. [http://www.conab.gov.br/conabweb/]

7. Vegetation fires: fire monitoring. [http://www.dpi.inpe.br/proarco/ bdqueimadas/].

8. Vasconcellos PC, Artaxo PE, Ciccioli P, Cecinato A, Brancaleoni E, Frattoni M: Chemical composition of aerosol collected in the amazon forest. Quim Nova 1998, 21:385-393.

9. Arbex MA, Cancado JED, Pereira LAA, Braga ALF, Saldiva PHN: Biomass burning and health effects. J Bras Pneumol 2004, 30:158-175. 
10. Bernstein JA, Alexis N, Barnes C, Bernstein IL, Bernstein JA, Nel A, Peden D, Diaz-Sanchez D, Tarlo SM, Williams PB: Health effects of air pollution. J Allergy Clin Immunol 2004, 114:1116-1123.

11. Freitas SR, Longo KM, Dias MAFS, Dias PLS: Emissões de queimadas em ecossistemas da América do Sul. Estud Av 2005, 19:167-185.

12. Hogervorst JG, de Kok TM, Briede JJ, Wesseling G, Kleinjans JC, van Schayck CP: Relationship between radical generation by urban ambient particulate matter and pulmonary function of school children. J Toxicol Environ Health A 2006, 69:245-262.

13. Woodruff TJ, Axelrad DA, Kyle AD, Nweke O, Miller GG, Hurley BJ: Trends in environmentally related childhood illnesses. Pediatrics 2004, 113:1133-1140.

14. Mascarenhas MDM, Vieira LC, Lanzieri TM, Leal APPR, Duarte AF, Hatch DL: Anthropogenic air pollution and respiratory disease-related emergency room visits in Rio Branco, Brazil - September, 2005. J Bras Pneumol 2008, 34:42-46.

15. PAHO: Assessment of health effects of ambient air pollution in Latin America and the Caribbean Washington DC: Pan American Health Organization; 2005.

16. Bateson TF, Schwartz J: Children's response to air pollutants. J Toxicol Environ Health A 2008, 71:238-243.

17. Nastos PT, Paliatsos AG, Anthracopoulos MB, Roma ES, Priftis KN: Outdoor particulate matter and childhood asthma admissions in Athens, Greece: a time-series study. Environ Health 2010, 9:45.

18. Braga AL, Saldiva PH, Pereira LA, Menezes JJ, Conceicao GM, Lin CA, Zanobetti A, Schwartz J, Dockery DW: Health effects of air pollution exposure on children and adolescents in Sao Paulo, Brazil. Pediatr Pulmonol 2001, 31:106-113.

19. Farhat SC, Paulo RL, Shimoda TM, Conceicao GM, Lin CA, Braga AL, Warth MP, Saldiva PH: Effect of air pollution on pediatric respiratory emergency room visits and hospital admissions. Braz J Med Biol Res 2005, 38:227-235.

20. Cançado JE, Saldiva PH, Pereira LA, Lara LB, Artaxo P, Martinelli LA, Arbex MA, Zanobetti A, Braga AL: The impact of sugar cane-burning emissions on the respiratory system of children and the elderly. Environ Health Perspect 2006, 114:725-729.

21. Migliore E, Berti G, Galassi C, Pearce N, Forastiere F, Calabrese R, Armenio L, Biggeri A, Bisanti L, Bugiani M, Cadum E, Chellini E, Dell'orco V, Giannella G, Sestini P, Corbo G, Pistelli R, Viegi G, Ciccone G: Respiratory symptoms in children living near busy roads and their relationship to vehicular traffic: results of an Italian multicenter study (SIDRIA 2). Environ Health 2009, 8:27-42.

22. Isidori $M$, Ferrara $M$, Lavorgna $M$, Nardelli A, Parrella A: In situ monitoring of urban air in Southern Italy with the tradescantia micronucleus bioassay and semipermeable membrane devices (SPMDs). Chemosphere 2003, 52:121-126.

23. Evans $\mathrm{HJ}$ : Historical perspectives on the development of the in vitro micronucleus test: a personal view. Mutat Res 1997, 392:5-10.

24. Marcato-Romain C-E, Guiresse M, Cecchi M, Cotelle S, Pinelli E: New direct contact approach to evaluate soil genotoxicity using the Vicia faba micronucleus test. Chemosphere 2009, 77:345-350.

25. Guimaraes ET, Domingos M, Alves ES, Caldini N, Lobo DJ, Lichtenfels AJ, Saldiva PH: Detection of the genotoxicity of air pollutants in and around the city of Sao Paulo (Brazil) with the Tradescantia-micronucleus (TradMCN) assay. Environ Exp Bot 2000, 44:1-8.

26. Lindberg HK, Wang $X$, Järventaus $H$, Falck GCM, Norppa H, Fenech M: Origin of nuclear buds and micronuclei in normal and folate-deprived human lymphocytes. Mutat Res 2007, 617:33-45.

27. Souza Lima E, Souza SR, Domingos M: Sensitivity of Tradescantia pallida (Rose) Hunt. 'Purpurea' Boom to genotoxicity induced by ozone. Mutat Res 2009, 675:41-45.

28. Alves ES, de Souza SR, Pedroso ANV, Domingos M: Potential of the TradMCN assay applied with inflorescences of Tradescantia pallida 'Purpurea' for evaluating air contamination by naphthalene. Ecotoxicol Environ Saf 2008, 71:717-721.

29. Carvalho-Oliveira R, Pozo RM, Lobo DJ, Lichtenfels AJ, Martins-Junior HA Bustilho JO, Saiki M, Sato IM, Saldiva PH: Diesel emissions significantly influence composition and mutagenicity of ambient particles: a case study in Sao Paulo, Brazil. Environ Res 2005, 98:1-7.

30. Ignotti E, Hacon SS, Silva AMC, Junger WL, CASTRO HA: Effects of biomass burning in Amazon: method to select municipalities using health indicators. Rev Bras Epidemiol 2007, 10:453-464.
31. Brazilian institute of geography and statistics - Cidades@. [http://www. ibge.gov.br/cidadesat/topwindow.htm?1].

32. Silva Dias MAF, Cohen JCP, Gandú AW: Clouds, rain and biosphere interactions in Amazon. Acta Amazon 2005, 35:215-222.

33. Rosa AM, Ignotti E, Hacon SS, Castro HA: Analysis of hospitalizations for respiratory diseases in Tangará da Serra, Brazil. J Bras Pneumol 2008 34:575-582.

34. Sugarcane crop mapping in Brazil by Earth observing satellite images. [http://www.dsr.inpe.br/mapdsr/]

35. Meireles J, Rocha R, Neto AC, Cerqueira E: Genotoxic effects of vehicle traffic pollution as evaluated by micronuclei test in tradescantia (TradMCN). Mutat Res 2009, 675:46-50.

36. Sisenando HA, Batistuzzo de Medeiros SR, Hacon SS: Tradescantia pallida: mais do que uma linda flor, um importante bioindicador da qualidade ambiental. Genetic na Escola 2009, 04:9-13.

37. Ma TH, Cabrera GL, Chen R, Gill BS, Sandhu SS, Vandenberg AL, Salamone MF: Tradescantia micronucleus bioassay. Mutat Res 1994, 310:221-230.

38. Fenech M: The cytokinesis-block micronucleus technique: a detailed description of the method and its application to genotoxicity studies in human populations. Mutat Res 1993, 285:35-44.

39. Decordier I, De Bont K, De Bock K, Mateuca R, Roelants M, Ciardelli R, Haumont D, Knudsen LE, Kirsch-Volders M: Genetic susceptibility of newborn daughters to oxidative stress. Toxicol Lett 2007, 172:68-84.

40. Neri M, Fucic A, Knudsen LE, Lando C, Merlo F, Bonassi S: Micronuclei frequency in children exposed to environmental mutagens: a review. Mutat Res 2003, 544:243-254.

41. Freitas SR, Silva Dias MAF, Silva Dias PL, Longo KM, Artaxo P, Andreae MO, Fischer $\mathrm{H}$ : A convective kinematic trajectory technique for low-resolution atmospheric models. J Geophys Res 2000, 105:375-386.

42. Freitas SR, Longo KM, Silva Dias MAF, Chatfield R, Silva Dias P, Artaxo P, Andreae MO, Grell G, Rodrigues LF, Fazenda A, Panetta J: The Coupled Aerosol and Tracer Transport model to the Brazilian developments on the Regional Atmospheric Modeling System (CATT-BRAMS). Part 1: Model description and evaluation. Atmos Chem Phys 2009, 9:2843-2861.

43. Carreras HA, Pignata ML, Saldiva PHN: In situ monitoring of urban air in Córdoba, Argentina using the Tradescantia-micronucleus (Trad-MCN) bioassay. Atmos Environ 2006, 40:7824-7830

44. Klumpp A, Ansel W, Fomin A, Schnirring S, Pickl C: Influence of climatic conditions on the mutations in pollen mother cells of Tradescantia clone 4430 and implications for the Trad-MCN bioassay protocol. Hereditas 2004, 141:142-148.

45. Savóia EJ, Domingos M, Guimaraes ET, Brumati F, Saldiva PHN: Biomonitoring genotoxic risks under the urban weather conditions and polluted atmosphere in Santo Andre, SP, Brazil, through Trad-MCN bioassay. Ecotoxicol Environ Saf 2009, 72:255-260.

46. Batalha JRF, Guimarães ET, Lobo DJA, Lichtenfels AJFC, Deur T, Carvalho HA Alves ES, Domingos M, Rodrigues GS, Saldiva PHN: Exploring the clastogenic effects of air pollutants in São Paulo (Brazil) using the Tradescantia micronuclei assay. Mutat Res 1999, 426:229-232.

47. Prajapati SK, Tripathi BD: Assessing the genotoxicity of urban air pollutants in Varanasi City using Tradescantia micronucleus (Trad-MCN) bioassay. Environ Int 2008, 34:1092-1096.

48. Andrade Júnior SJ, Santos Júnior JCS, Oliveira JL, Cerqueira EMM, Meireles JRC: Micronuclei in tetrads of Tradescantia pallida (Rose) Hunt. cv. purpurea Boom: genetic changes caused by urban air pollution. Acta Sci Biol Sci 2008, 30:295-301.

49. Mariani RL, Martins Jorge MP, Pereira SS, Melione LP, Carvalho-Oliveira R, Ma TH, Saldiva PHN: Association between micronuclei frequency in pollen mother cells of Tradescantia and mortality due to cancer and cardiovascular diseases: A preliminary study in Sao Jose dos Campos, Brazil. Environ Pollut 2009, 157:1767-1770.

50. Ferreira MI, Rodrigues GS, Domingos M, Saldiva PHN: In situ monitoring of mutagenicity of air pollutants in São Paulo City using Tradescantia-SHM bioassay. Braz Arch Biol Technol 2003, 46:253-258.

51. Alves ES, Giusti PM, Domingos M, Saldiva PHN, Guimarães ET, Lobo DJ: Anatomic studies on Tradescantia hibrid clone 4430 leaves: changes caused by urban air pollution. Rev Bras Bot 2001, 24:597-576.

52. WHO: Air Quality Guidelines: Global Update 2005. Particulate matter, ozone, nitrogen dioxide and sulfur dioxide Copenhagen: WHO Regional Office for Europe; 2005. 
53. Annesi-Maesano I, Moreau D, Caillaud D, Lavaud F, Le Moullec Y, Taytard A, Pauli G, Charpin D: Residential proximity fine particles related to allergic sensitisation and asthma in primary school children. Respir Med 2007, 101:1721-1729.

54. Braga AL, Pereira LA, Procopio M, Andre PA, Saldiva PHN: Association between air pollution and respiratory and cardiovascular diseases in Itabira, Minas Gerais State, Brazil. Cad Saude Publica 2007, 23(Suppl 4): S570-S578.

55. Casas SB, Peña-Cortés F, Bustingorry SO: Effect for particles material atmospheric pollution on acute respiratory diseases in under 5 years of age. Cienc enferm 2004, 10:21-29.

56. Rojas-Martinez R, Perez-Padilla R, Olaiz-Fernandez G, Mendoza-Alvarado L, Moreno-Macias H, Fortoul T, McDonnell W, Loomis D, Romieu I: Lung function growth in children with long-term exposure to air pollutants in Mexico City. Am J Respir Crit Care Med 2007, 176:377-384.

57. Kajekar R: Environmental factors and developmental outcomes in the lung. Pharmacol Ther 2007, 114:129-145.

58. Mazzoli-Rocha F, Magalhaes CB, Malm O, Saldiva PHN, Zin WA, Faffe DS: Comparative respiratory toxicity of particles produced by traffic and sugar cane burning. Environ Res 2008, 108:35-41.

doi:10.1186/1476-069X-10-41

Cite this article as: Sisenando et al:: Genotoxic potential generated by biomass burning in the Brazilian Legal Amazon by Tradescantia micronucleus bioassay: a toxicity assessment study. Environmental Health 2011 10:41

\section{Submit your next manuscript to BioMed Central} and take full advantage of:

- Convenient online submission

- Thorough peer review

- No space constraints or color figure charges

- Immediate publication on acceptance

- Inclusion in PubMed, CAS, Scopus and Google Scholar

- Research which is freely available for redistribution

Submit your manuscript at www.biomedcentral.com/submit 